\title{
Decadal water balance of a temperate Scots pine forest (Pinus sylvestris L.) based on measurements and modelling
}

\author{
B. Gielen ${ }^{1}$, H. Verbeeck ${ }^{2}$, J. Neirynck ${ }^{3}$, D. A. Sampson ${ }^{4}$, F. Vermeiren ${ }^{3}$, and I. A. Janssens ${ }^{1}$ \\ ${ }^{1}$ University of Antwerp, Research Group Plant and Vegetation Ecology, Universiteitsplein 1, 2610 Wilrijk, Belgium \\ ${ }^{2}$ Ghent University, Laboratory of Plant Ecology, Department of Applied Ecology and Environmental Biology, Faculty \\ Bioscience Engineering, Coupure Links 653, 9000 Ghent, Belgium \\ ${ }^{3}$ Research Institute for Nature and Forest, Gaverstraat 4, 9500 Geraardsbergen, Belgium \\ ${ }^{4}$ Arizona State University, Decision Center for a Desert City, Global Institute of Sustainability, Tempe, AZ 85287, USA
}

Received: 5 October 2009 - Published in Biogeosciences Discuss.: 11 November 2009

Revised: 23 March 2010 - Accepted: 24 March 2010 - Published: 13 April 2010

\begin{abstract}
We examined the water balance components of an 80-year-old Scots pine (Pinus sylvestris L.) forest stand in the Campine region of Belgium over a ten year period using five very different approaches; our methods ranged from data intensive measurements to process model simulations. Specifically, we used the conservative ion method (CI), the Eddy Covariance technique (EC), an empirical model (WATBAL), and two process models that vary greatly in their temporal and spatial scaling, the ORCHIDEE global land-surface model and SECRETS a stand- to ecosystemscale biogeochemical process model. Herein we used the EC technique as a standard for the evapotranspiration (ET) estimates. Using and evaluating process based models with data is extremely useful as models are the primary method for integration of small-scale, process level phenomena into comprehensive description of forest stand or ecosystem function. Results demonstrated that the two process models corresponded well to the seasonal patterns and yearly totals of ET from the EC approach. However, both WATBAL and CI approaches overestimated ET when compared to the EC estimates. We found significant relationships between several meteorological variables (i.e., vapour pressure deficit [VPD], mean air temperature $\left[T_{\text {air }}\right]$, and global radiation $[R g]$ ) and ET on monthly basis for all approaches. In contrast, few relationships were significant on annual basis. Independent of the method examined, ET exhibited low inter-annual variability. Consequently, drainage fluxes were highly correlated with annual precipitation for all approaches examined, except CI.
\end{abstract}

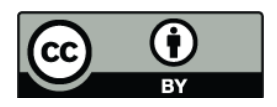

Correspondence to: B. Gielen (bert.gielen@ua.ac.be)

\section{Introduction}

Vegetation strongly interacts with the terrestrial water cycle to influence runoff processes within vegetated catchments (Sahin and Hall, 1996). Forests play an important role in the water and energy balance of the land surface. Complex diurnal cycles of water evaporation and energy fluxes are generated by the forest floor, and from beneath and within the forest canopy; vegetation structure and canopy height strongly influence these water cycling processes (Rutter, 1975). Consequently, forests influence the magnitude and patterns of rainfall at regional and global scale by influencing the low level moisture convergence, and they determine the amount of water that flows within the river basin (Shukla and Mintz, 1982). Long term forest monitoring sites can provide a wealth of knowledge on the drivers of the interannual and long term seasonal variation of the water balance components, such as evapotranspiration (ET) and drainage of forests. Many different approaches ranging from measurements and empirical models to generic and site parameterised process-based models have been used to estimate ecosystem water balances.

The eddy covariance technique, a measurement-based approach, provides measures of latent heat flux, the energy flux density equivalent of the ET rate, and offers promising estimates for closing the water balances of ecosystems (Aubinet et al., 2000; Baldocchi and Meyers, 1998). A less common approach uses conservative ion concentrations in throughfall water and in soil water below the root zone (Eriksson and Khunakasem, 1969) to estimate ET. Finally, many different models have been used to estimate ET at the stand-scale. Empirical models, such as WATBAL, are less complicated and can calculate ET based on the Jensen and Haise equation by

Published by Copernicus Publications on behalf of the European Geosciences Union. 
using a set of input parameters derived from commonly available data (Starr, 1999). Conversely, complex process-based models simulate the different subcomponents of water balance (e.g., canopy evaporation, soil evaporation, and transpiration) by using process-level algorithms. Using and evaluating process based models with data is extremely useful as models are the primary method for integration of small-scale, process level phenomena into comprehensive description of forest stand or ecosystem function (Hanson et al., 2004). Each approach, however, has merits and drawbacks that depend on the research question and the scale of focus. Methods to estimate evapotranspiration vary in at least three ways: 1) each technique has an inherent, representative spatial and temporal scale that makes either interpolation or extrapolation necessary to make inferences outside of these scales, 2) techniques differ in whether they measure evapotranspiration or just one or several of its components, and 3) a unique set of particular assumptions, technical difficulties, measurement errors and biases are necessarily introduced with each technique employed (Wilson et al., 2001) Notwithstanding, comparing multiple approaches for one site may provide insight into the process drivers of ET and drainage over multiple spatial and temporal scales as they influence forest water balance.

Climate change (one of many global change issues) influences many more processes than the commonly reputed effects on global temperatures; associated changes in the hydrologic cycle often have even greater societal impacts than temperature through changes in precipitation, ET, runoff, and water available for human use (Chapin et al., 2008). Climate change (i.e. increased temperatures, vapour pressure deficit (VPD) and $\mathrm{CO}_{2}$ concentrations) may alter ET and, consequently, drainage from forested ecosystems (Betts et al., 2007; Teuling et al., 2009).

We can study the potential effects of altered climate on forest ET by using a process based modelling approach. A better understanding of the role of vegetation in catchment hydrology can thus improve both hydrological predictions, and mitigation of global change through adaptive management strategies (Bonan, 2008; Jackson et al., 2008). Furthermore, it is argued that climate change will intensify the global water cycle which will result in increased global precipitation and consequently increased runoff depending on the effect on ET (Huntington, 2006). Therefore it is essential to study the effect of climatological variables on ET based on long time data series.

The objectives of this paper are: 1) to compare and contrast measured versus modelled estimates of ET for a Scots pine forest using five approaches (SECRETS, ORCHIDEE, WATBAL, EC, CI) 2) to study intra-annual and interannual variability of ET and drainage for this forest.

\section{Material and methods}

\subsection{Plot description}

The experimental forest "De Inslag" is located in Brasschaat, $20 \mathrm{~km} \mathrm{NE}$ of Antwerp in the Belgian Campine region $\left(51^{\circ} 18^{\prime} \mathrm{N}, 4^{\circ} 31^{\prime} \mathrm{E}\right)$. The study site consists of a $2.0 \mathrm{ha}, 80-$ year-old even aged Scots pine stand situated within a $150 \mathrm{ha}$ mixed coniferous/deciduous forest which is part of the ICP Forests level II and Fluxnet/CarboEurope-IP networks. The forest that surrounds the site consists of several broadleaf species, some native, such as Betula pendula Roth., Quercus robur L. and Sorbus aucuparia L., and some introduced species such as, Quercus rubra L. and Castanea sativa Mill. The non-native understorey, which was mainly comprised of Prunus serotina Ehrh., was removed in 1993. Since then, a small but steady recolonisation of the shrub layer by Betula species and Sorbus aucuparia L. has occurred. Following the understory removal Molinea caerulea L. Moench. has emerged along with Rubus species and Dryopteris ferns. The site has a temperate maritime climate, with a long-term mean annual temperature of $11.1^{\circ} \mathrm{C}$. The long-term mean temperatures of the coldest and warmest months are 3 and $19^{\circ} \mathrm{C}$ respectively, and mean annual precipitation is $824 \mathrm{~mm}$. The site has a flat topography (slope: $0.3 \%$ ) with an elevation of $16 \mathrm{~m}$ a.s.l. The soil is covered with an organic surface layer of $7.5 \mathrm{~cm}$ depth. A deep Aeolian cover sand layer (Dryas III) rests on a substratum of Clay of the Campine (40\% of clay) (Tiglian) at variable depth, between 1.2 and $2.5 \mathrm{~m}$ and more. The upper soil is rarely saturated, because of rapid hydraulic conductivity in the upper horizons. During wet periods in winter a perched water table is often present above the clay layer. According to the World Reference Base for Soil Resources version 2006 (WRB, 2006), the soil is classified as an Albic Hypoluvic Arenosol. In 1995 tree density was 538 trees ha $^{-1}$. In the winter of 1999163 trees ha $^{-1}$ were harvested which decreased tree density to $375 \mathrm{stems} \mathrm{ha}^{-1}$ (Xiao et al., 2003). Stand inventories in 2001 and 2003 indicate that no further reduction in tree density occurred during the study period (1997-2006) (Yuste et al., 2005).

\subsection{Measurements}

\subsubsection{Eddy covariance}

The vertical flux of $\mathrm{CO}_{2}$ and $\mathrm{H}_{2} \mathrm{O}$ above the canopy were measured using the eddy covariance technique (EC) (Baldocchi and Meyers, 1998). Fluxes of $\mathrm{CO}_{2}$ and $\mathrm{H}_{2} \mathrm{O}$ were measured continuously since mid 1996, using a sonic anemometer (Model SOLENT 1012R2, Gill Instruments, Lymington, UK) for wind speed and an infrared gas analyser (IRGA) (Model LI-6262, LI-COR Inc., Lincoln, NE, USA) for gaseous concentrations. Measurements were made at the top of a $41 \mathrm{~m}$ tower centrally located within the stand. The instruments are installed at approximately $18 \mathrm{~m}$ above the canopy. 
Detailed description of the experimental setup can be found in Kowalski et al. (2000) and Carrara et al. (2003). Half hourly latent heat (or ET) fluxes were calculated following the recommendations of the Euroflux network (Aubinet et al., 2000; Papale et al., 2006; Reichstein et al., 2005). Gapfilling was done using mean diurnal courses (14-d moving average) and annual sums were calculated as the sum of halfhour fluxes. Only years with at least $70 \%$ of original half hourly data were considered in this analysis, thus 1998, 1999 and 2003 have no yearly EC sums. The Energy balance closure was calculated as described by Carrara et al. (2003) and aggregated on daily basis. Latent heat fluxes were corrected for the energy balance closure as described by Barr et al. (1994) and Blanken et al. (1997). This adjustment is sometimes referred as "Bowen ratio closure" because it is based on the assumption that the Bowen ratio is correctly measured (Twine et al., 2000).

A Self-Organizing Map neural network was used as a simplified approach to estimate the random uncertainty on the latent heat fluxes. The Self-Organizing Map is a well established artificial neural network for processing highdimensional data (Kohonen, 2001; Oja et al., 2002). We used Self-Organizing Maps to cluster days based on the observed air temperature, observed global radiation, observed vapor pressure deficit, gap-filled soil water content observations and the sinus of day of year on a daily basis. The SelfOrganizing Map distinguished 72 clusters with an average of 5 observations per clusters allowing generalization while avoiding overfitting the Self-Organizing Maps. For each of the 72 clusters, the daily aggregated latent heat observations were then assigned to their corresponding climate conditions and the standard deviation of latent heat flux was calculated. Standard error propagation was applied to obtain uncertainty estimates with a lower temporal resolution. A short description of Self-Organizing Maps can be found in Luyssaert et al. (2007).

\subsubsection{Conservative Ions}

Conservative ions (CI), such as $\mathrm{Na}^{+}$and $\mathrm{Cl}^{-}$, are not likely to be evaporated, therefore, their soil water concentrations increase for lower soil profiles. The difference in concentrations of CI measured in through-fall and in soil water below the root zone can thus be used to estimate the ET (Eriksson and Khunakasem, 1969). Concentration measurements of $\mathrm{Cl}^{-}$were done biweekly at three points within the study plot at $75 \mathrm{~cm}$ below soil surface and in through-fall water.

Chemical composition of through-fall water was sampled twice per month with 10 systematically distributed bulk collectors in an adjacent 0.25 ha large plot. They consisted of a polyethylene funnel $(14 \mathrm{~cm} \varnothing)$ placed at a standard height of $1 \mathrm{~m}$, which was connected to a subterranean 21 polyethylene bottle. A nylon mesh was placed in the funnel to avoid contamination by large particles and debris. At every sampling, through-fall volumes from the collectors were recorded in the field and a pooled sample was taken as a weighted average from all collectors. Funnels and bottles were replaced at every sampling event. Samples were kept cool in iceboxes during transport. Fractions of chloride $\left(\mathrm{Cl}^{-}\right)$were analysed using ion chromatography (Dionex DX-100). Monthly seepage fluxes leaving the soil compartment were determined by multiplying the ratio of monthly chloride $\left(\mathrm{Cl}^{-}\right)$through-fall concentrations to monthly averaged $\mathrm{Cl}^{-}$concentration with the monthly precipitation collected in the through-fall collectors below the canopy. Monthly seepage fluxes were summed to obtain the yearly seepage flux.

\subsubsection{Additional field measurements}

Additional measurements collected for the site included estimates of soil water content (SWC), leaf area index (LAI), and meteorological data. Volumetric soil water content was measured using two series of TDR sensors (Time Domain Reflectometry), at two places within the experimental plot twice a week from 1997 to 2003 and weekly during the remaining 3 years. At each of the two sample points SWC was measured every $25 \mathrm{~cm}$ until a depth of $175 \mathrm{~cm}$. A 10 -year daily time series of projected LAI $\left(\mathrm{m}^{2} \mathrm{~m}^{-2}\right)$ was reconstructed using a fixed seasonal pattern that was measured in 2007 (Op de Beeck et al., 2010). Yearly maxima were derived from measurements recorded in 1999 (Gond et al., 1999), 2003 (Konopka et al., 2005) and 2007 (Op de Beeck et al., 2010).

Meteorological data included half-hourly data recorded at the top of the tower: Global radiation (Kipp and Zonen CM6B, the Netherlands), net radiation (REBS 07, Seattle , WA, USA), temperature and relative humidity (Didcot Instrument Co Ltd, Abingdon, United Kingdom DTS-5A), atmospheric pressure (SETRA Barometric Pressure transducer Model 278, Setra systems, Boxborough, MA), wind speed (Didcot DWR-205G) and precipitation (Didcot DRG-51). Two heat flux plates (Campbell HFT03, CSI, Logan, UT, USA) measured soil heat flux. All meteorological variables were measured at $0.1 \mathrm{~Hz}$ and half hourly means were stored on a data logger (Campbell CR10, UK).

Missing data for Air temperature, relative humidity, atmospheric pressure, wind speed and precipitation were obtained from a weather station at Luchtbal which is within $10 \mathrm{~km}$ from the research site. Because global radiation was not available at this station, it was obtained from the closest possible location which is at $50 \mathrm{~km}$ in Uccle.

Sap flow measurements were conducted from 26 May to 18 October 2000 using the heat field deformation (HFD) method. The HFD method is based on observed changes in an artificial heat field around a linear heater inserted into individual tree stems (Nadezhdina et al., 2004, 2006; Nadezhdina, 2000). Sap flow was measured on 14 representative trees which were selected based on quantils of total of a forest inventory (Xiao et al., 2003). A more detailed description of the measurements can be found in Verbeeck et al. (2007). Sap flow was scaled-up to ecosystem transpiration 
using biometric parameters. This approach was described by Cermák et al. (2004) as suited for even aged stands, and uses the ratio of basal area at plot scale to that of the measurement trees to scale-up the sap flow measurements to stand scale transpiration.

\subsection{Model descriptions}

\subsubsection{SECRETS}

The Stand to Ecosystem CaRbon and EvapoTranspiration Simulator (SECRETS) model was written to simulate standto ecosystem-scale carbon and water fluxes at this research site (Sampson et al., 2001). Accordingly, SECRETS can simulate multi-species multi-structured stands; stand-scale estimates of carbon and water fluxes may result from species dependent processes occurring in the over-story, sub-story, under-story or any combination of the three depending on the stand structure simulated. Of course, SECRETS models the attenuation of light through the vegetation layers present and, thus, incident radiation to the forest floor. This biogeochemical process model estimates carbon (Sampson et al., 2006) and water (Meiresonne et al., 2003) pools and fluxes for simple (Sampson and Ceulemans, 2000) or complex (Sampson et al., 2006) species associations.

The model simulates stand-scale carbon and water fluxes using established process algorithms adapted from several sources. Namely, the model uses maintenance respiration $\left(R_{M}\right)$ and water balance formulations adapted from BIOMASS (McMurtrie and Landsberg, 1992), with photosynthesis modelled using the Farquhar formulation found in the sun/shade model (dePury and Farquhar, 1997). Soil water holding capacity is calculated from the soil sand and clay fractions following Saxton et al. (1986). Daily estimates of tissue-specific $R_{M}$ are derived by integration using diurnal trends in temperature and estimates of standing mass in standard $Q_{10}$ equations. Transpiration and evaporation estimates are derived from integration using PenmanMonteith equations however under-story estimates are based on formulations by Kelliher et al. (1986). Daily estimates of transpiration are calculated from hourly estimates of water vapour conductance using the Ball-Woodrow-Berry model adapted by Leuning (1995). The SECRETS model simulates photosynthesis for both sun and shade leaves and needles on an hourly (or half-hourly) time-step. Although most process-level outputs are available for these analyses we focused on the components of water balance that included canopy interception, evaporation, transpiration, throughfall, stem flow, and surface and soil water evaporation (all in units of $\mathrm{mm} \mathrm{d}^{-1}$ ). A flow diagram of the model may be found in Sampson et al. (2001).

\subsubsection{ORCHIDEE}

ORCHIDEE (Krinner et al., 2005) is a process-oriented integrated global land-surface model consisting of three sub modules: a global land surface scheme (Ducoudre et al., 1993) and a global continental carbon cycle model. The model simulates the diurnal cycle of turbulent fluxes of $\mathrm{CO}_{2}$, water, and energy, while the ecosystem carbon and water dynamics (i.e., carbon allocation, plant respiration, growth, mortality, soil organic matter decomposition, water infiltration and runoff) are calculated at a daily time step. As in most global biogeochemical models, Plant Functional Types (PFTs) are used to classify vegetation at any particular site. ORCHIDEE simulates 13 PFTs at the globe scale, with all PFTs sharing the same equations but using different parameter values. Plant phenology is one exception, where PFTspecific equations exist (Botta et al., 2000). For this study ORCHIDEE was run at local scale ("grid point mode") using the half-hourly meteorological forcing measured at the site. We used the "temperate evergreen needle-leaf forest", a PFT found in ORCHIDEE, as a surrogate for the Scots pine at Brasschaat for which the standard parameter values were used. Phenology was simulated prognostically with a prescribed maximum LAI. ORCHIDEE provided outputs for transpiration, soil evaporation and canopy evaporation on daily basis. We initialized biomass and soil carbon pools to equilibrium values from a 2000 year long spin-up driven by cycling the 10 year available climate inputs. This resulted in a total living biomass of $6594 \mathrm{~g} \mathrm{C} \mathrm{m}^{-2}$ and a total soil carbon pool (mineral soil and litter) of $7279 \mathrm{~g} \mathrm{C} \mathrm{m}^{-2}$. These values are in the same order of magnitude as the inventory estimates of Yuste et al. (2005): $8450 \mathrm{~g} \mathrm{C} \mathrm{m}^{-2}$ in the living biomass and $6650 \mathrm{~g} \mathrm{C} \mathrm{m}^{-2}$ in the soil and litter. Uncertainties on the simulated carbon stocks will mainly influence the respiration and not the water fluxes simulated for this study. Moreover the simulated leaf biomass $\left(196 \mathrm{~g} \mathrm{C} \mathrm{m}^{-2}\right)$ - one of the main drivers of the ecosystem transpiration - corresponds well to the estimate of the inventory $170 \mathrm{~g} \mathrm{C} \mathrm{m}^{-2}$ (Yuste et al., 2005).

\subsubsection{WATBAL}

WATBAL (Starr, 1999) uses water balance calculations typically found in simple temperature-based models (Thornthwaite and Mather, 1957; Xu and Singh, 1998), however potential ET in WATBAL is estimated from global radiation and based on the relationship between air temperature and the ratio between evaporation and global radiation - or the Alfalfa reference method - as found in Jensen and Haise (1963). It calculates evaporative heat flux density, which is then converted into $\mathrm{mm}$ of potential ET using the latent heat of vaporization (De Vries et al., 2007). A crop factor, as described in Meiresonne et al. (2003), uses a seasonal pattern in values that range between 1.07 and 1.18 to convert potential evaporation for the reference crop into one for forest. ET is then computed by comparing water supply with water demand, 
taking into account soil water availability. Although WATBAL was principally based on an end-of-the-month book keeping methodology, Starr (unpublished data) altered the model to enable daily simulations of soil water balance for several water balance components: daily precipitation inflow, daily drainage (soil water flux) and ET outflows, and daily changes in soil water storage. WATBAL uses daily mean air temperature, precipitation and global radiation (or cloud cover) as meteorological input.

WATBAL is included in this study because it is a potential candidate to be used for a multi site water balance study within the ICP-forest network.

\subsection{Water balance}

Water balance estimates for the five approaches range greatly from pure data driven methods (CI and EC) to an empirical approach (WATBAL), to process models (ORCHIDEE and SECRETS). All five approaches gave us an estimate for ET or drainage, which was then used to calculate the missing term from the water balance equation:

$\mathrm{P}=\mathrm{ET}+$ drainage $\pm \Delta \mathrm{SWC}+\mathrm{R}$

Where: $\mathrm{P}$ is total precipitation $\left(\mathrm{mm} \mathrm{a}^{-1}\right)$, ET $\left(\mathrm{mm} \mathrm{a}^{-1}\right)$ was previously described, $\triangle \mathrm{SWC}$ is the difference in soil water content, $\mathrm{R}$ is horizontal runoff $\left(\mathrm{mm} \mathrm{a}^{-1}\right)$ and drainage is vertical water loss. For these analyses we assume that $\mathrm{R}$ is equal to zero because of the high hydraulic conductivity of the soil and no sloping terrain at our site. In addition to daily estimates of ET the two process models, ORCHIDEE and SECRETS, also estimated the subcomponents of ET: transpiration, soil evaporation, and canopy evaporation.

\section{Results}

\subsection{Climatic conditions}

Rainfall varied considerably during the course of this investigation (Fig. 1). Of the ten years examined, the driest year was 1997 which exhibited a total rainfall of $671 \mathrm{~mm} ; 470 \mathrm{~mm}$ (70\%) fell during the growing season (which generally starts 1st April and lasts until 31st October. In contrast, the wettest year was 1998, with a total of $1041 \mathrm{~mm}$, of which $793 \mathrm{~mm}$ ( $72 \%$ ) fell during the growing season. Mean yearly temperature was the lowest in $1997\left(10.6^{\circ} \mathrm{C}\right)$ and highest in 2006 $\left(11.9^{\circ} \mathrm{C}\right)$. The coldest month was observed in January 1997 , with mean monthly temperature of $-0.8^{\circ} \mathrm{C}$. The warmest month was measured in July 2006, with a mean monthly temperature of $22.4^{\circ} \mathrm{C}$ (Fig. 1).

Distinct diurnal and seasonal patterns in the meteorological variables that drive water flux and, thus, site water balance were evident for our site (Fig. 2). Note that there were no gap filled EC measurements available for 1998, 1999, and 2003 ( $<70 \%$ data coverage). Closure of the surface energy

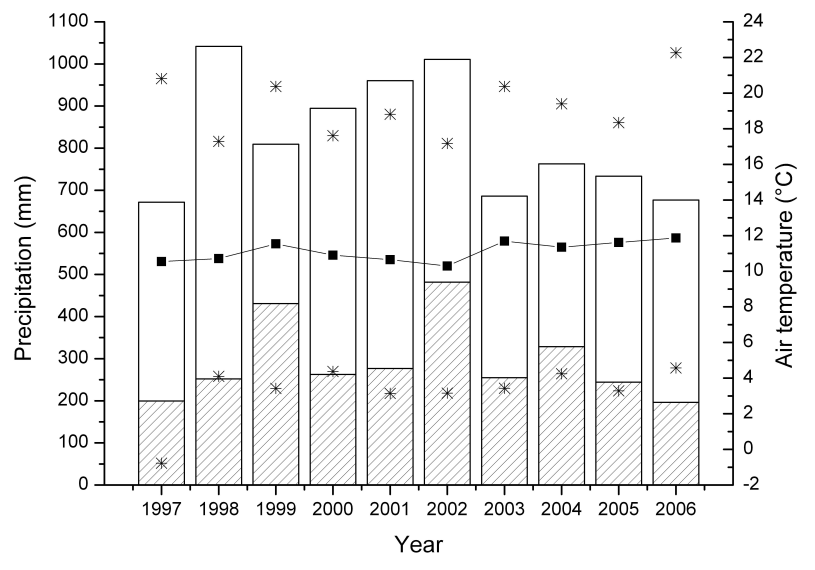

Fig. 1. Summary of the meteorological data measured on a $41 \mathrm{~m}$ centrally located tower within the study site during the period from 1997 through 2006 (abscissa). The left ordinate axis displays yearly precipitation $(\mathrm{mm})$ during the dormant season (dashed bar graph) and the growing season (open bars). The right ordinate displays average yearly temperature $\left({ }^{\circ} \mathrm{C}\right)$ (line graph: asterisks indicate lowest and highest mean monthly temperatures).

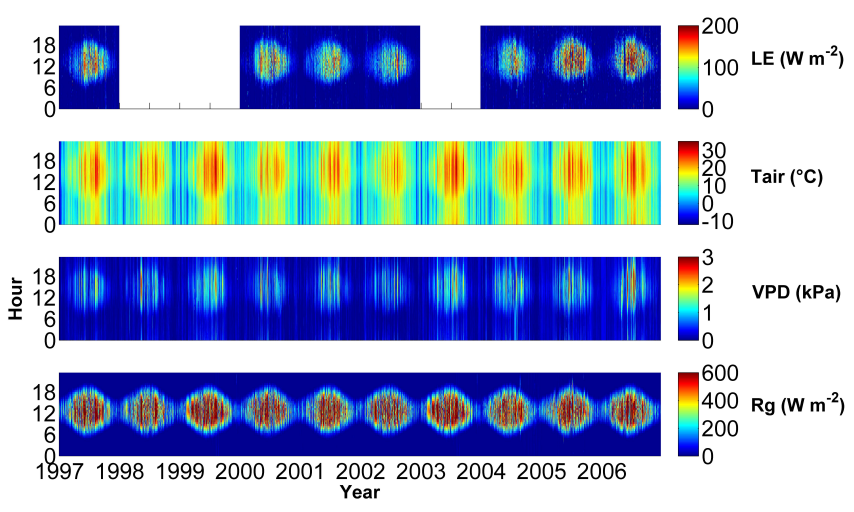

Fig. 2. Latent heat $\left(\mathrm{LE}-\mathrm{W} \mathrm{m}{ }^{-2}\right)$, air temperature $\left(T_{\text {air }}{ }^{\circ} \mathrm{C}\right)$, vapour pressure deficit (VPD- $\mathrm{kPa})$ and incident (global) radiation $(R g-$ $\mathrm{W} \mathrm{m}^{-2}$ ) during the study period. Data reflect half-hourly measurements from the top of a $41 \mathrm{~m}$ tower located within the study site by year (abscissa) and hour of the day (ordinate). The color bar at the right of the figure indicates the magnitude of the response for each variable.

balance, which is used as a quality test for eddy covariance data (Wilson et al., 2002), was calculated by comparing daily total fluxes of net radiation against the sums of sensible heat flux, latent heat flux, soil heat flux and storage in the biomass. The mean energy balance closure was $84 \%$ over the seven years of measurements (Table 1), which considered normal for eddy covariance measurements over a tall forest (Aubinet et al., 2000; Wilson et al., 2002). 
Table 1. The closure of the surface energy balance was calculated by comparing daily total fluxes of net radiation $\left(\mathrm{W} \mathrm{m}^{-2}\right)$ against the sums of sensible heat flux $\left(\mathrm{W} \mathrm{m}^{-2}\right)$, latent heat flux $\left(\mathrm{W} \mathrm{m}^{-2}\right)$, soil heat flux $\left(\mathrm{W} \mathrm{m}^{-2}\right)$ and heat storage $\left(\mathrm{W} \mathrm{m}^{-2}\right)$. In all cases the model used was: $y(x)=a^{*} x+b$. Included in the table are estimates of the coefficient of determination $\left(r^{2}\right)$ and the $p$-values for each regression analysis.

\begin{tabular}{rrrrr}
\hline Year & $b$ & $a$ & $r^{2}$ & $p$-value \\
\hline 1997 & -745 & 0.79 & 0.85 & $p<0.01$ \\
2000 & -1095 & 0.81 & 0.76 & $p<0.01$ \\
2001 & -1323 & 0.83 & 0.82 & $p<0.01$ \\
2002 & -1124 & 0.78 & 0.83 & $p<0.01$ \\
2004 & -966 & 0.81 & 0.81 & $p<0.01$ \\
2005 & -441 & 0.84 & 0.73 & $p<0.01$ \\
2006 & -435 & 0.89 & 0.72 & $p<0.01$ \\
\hline
\end{tabular}

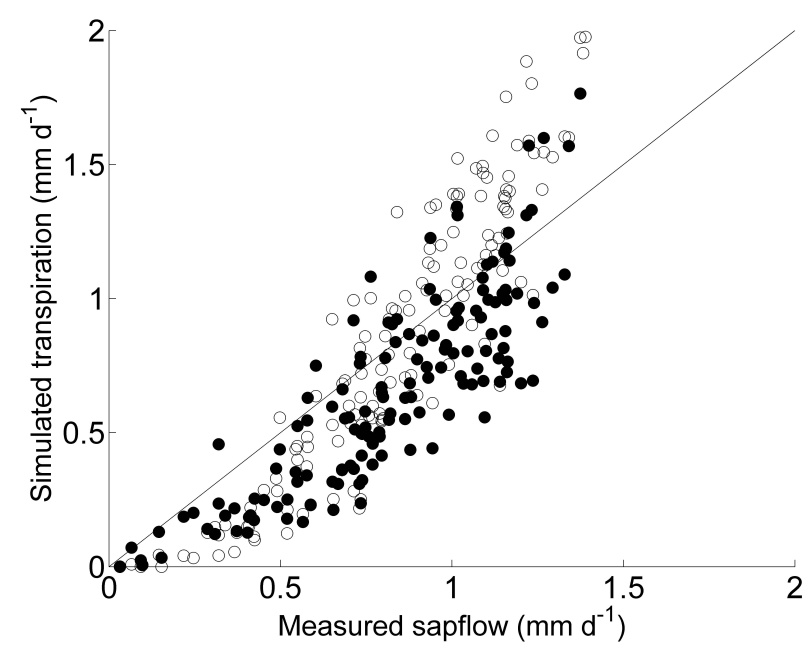

Fig. 3. The relationship between canopy transpiration $\left(\mathrm{mm} \mathrm{d}^{-1}\right)$ simulated by (SECRETS (•) and ORCHIDEE (o) (ordinate) and upscaled estimates from sap flow (abscissa) measured over a period of 120 days in 2001. The solid line depicts the 1:1 relationship.

\subsection{Model evaluation}

Model simulations suggest that transpiration represented the dominant portion of the annual ET flux (on average, 55\% for SECRETS and $65 \%$ for ORCHIDEE). Therefore, the simulated transpiration was evaluated with estimates of transpiration from sap flow data (Fig. 3). ORCHIDEE overestimated the measured sap flow by $8 \%\left(r^{2}=0.76\right)$ while SECRETS underestimated measured sap flow by, on average, $14 \%\left(r^{2}=0.67\right)$. Total stand-scale ET simulated by the models was compared to monthly estimates of the latent heat fluxes (Fig. 4). Results indicated that both SECRETS and ORCHIDEE performed well, although both models slightly overestimated the ET in the lower range up to $0.5 \mathrm{~mm} \mathrm{~d}^{-1}$. SECRETS demonstrated good correspondence to the mea-

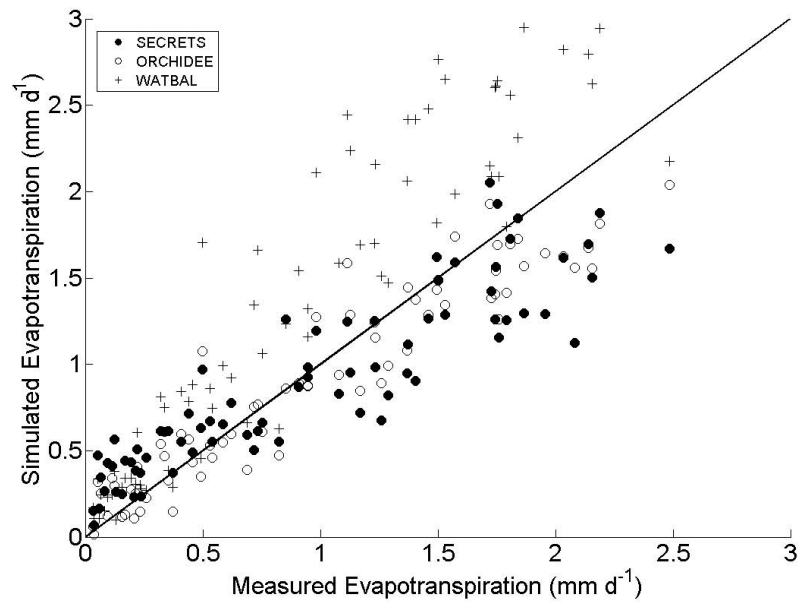

Fig. 4. Mean monthly estimates of latent heat flux measured by eddy covariance (abscissa- $\mathrm{mm} \mathrm{d}^{-1}$ ) and model estimates (ordinate) for SECRETS (•), ORCHIDEE (o) and WATBAL (+). The solid line represents the 1:1 relationship.

sured latent heat flux $\left(r^{2}=0.69\right)$, underestimating ET by only $3 \%$. ORCHIDEE underestimated the latent heat fluxes by $7 \%$ but with less variance $\left(r^{2}=0.86\right)$. On average, estimates obtained from WATBAL were $73 \%\left(r^{2}=0.82\right)$ greater than the measured latent heat fluxes. Additionally, ORCHIDEE and SECRETS simulated canopy evaporation, which were $(22 \pm 1 \%)$ and $(6 \pm 1 \%)$ of annual ET, respectively.

\subsection{Approach comparison}

\subsubsection{Annual estimates}

Box and wisker plots of the seven-year mean annual ET (recall, we have no gapfilled EC data for 1998, 1999 and 2003) for the five methods indicated that the two process models ORCHIDEE $(291 \pm 28 \mathrm{~mm})$ and SECRETS $(304 \pm 28 \mathrm{~mm})$ (Fig. 5a) produced the lowest estimate of ET, followed by the EC approach $(321 \pm 33 \mathrm{~mm})$. Both process models fall within the ranges of the estimated uncertainty of the EC measurements (Table 6) which is on average $22 \%$ of the annual ET. WATBAL $(475 \pm 30 \mathrm{~mm})$ and CI $(505 \pm 77 \mathrm{~mm})$ both overestimated ET when compared to the EC measurements. Simulation and measurement based results for drainage were the opposite; estimates of latent heat fluxes from the process based models SECRETS $(516 \pm 129 \mathrm{~mm})$ and ORCHIDEE $(529 \pm 137 \mathrm{~mm})$ were highest of the five methods examined, followed by EC $(499 \pm 144 \mathrm{~mm})$. Finally, WATBAL $(346 \pm 134 \mathrm{~mm})$ and CI $(310 \pm 101 \mathrm{~mm})$ underestimated drainage when compared to the EC-based measurements. 
Table 2. Coefficients for the linear regression analyses between ET (based on monthly totals) estimated by the four different approaches (SECRETS, ORCHIDEE, WATBAL, eddy covariance [EC]) and the meteorological variables (i.e., mean monthly VPD; kPa, mean monthly air temperature $\left[T_{\text {air }}\right.$; Celsius $]$ and monthly total global radiation $\left[R g ; \mathrm{MJ} \mathrm{m}^{-2}\right.$ month $\left.\left.^{-1}\right]\right)$ for each of the four methods. In all cases the model used was: $y(x)=a^{*} x+b$. Included in the table are estimates of the coefficient of determination $\left(r^{2}\right)$ and the $p$-values for each regression analysis.

\begin{tabular}{|c|c|c|c|c|c|c|c|c|c|c|c|c|}
\hline & \multicolumn{4}{|c|}{ VPD } & \multicolumn{4}{|c|}{$T_{\text {air }}$} & \multicolumn{4}{|c|}{$R g$} \\
\hline & $b$ & $a$ & $r^{2}$ & $p$-value & $b$ & $a$ & $r^{2}$ & $p$-value & $b$ & $a$ & $r^{2}$ & $p$-value \\
\hline SECRETS & 6.3 & 63 & 0.61 & $p<0.01$ & -5.6 & 2.82 & 0.83 & $p<0.01$ & 2.8 & 0.08 & 0.76 & $p<0.01$ \\
\hline ORCHIDEE & -1.1 & 84 & 0.75 & $p<0.01$ & -13.6 & 3.45 & 0.86 & $p<0.01$ & -5.6 & 0.10 & 0.92 & $p<0.01$ \\
\hline WATBAL & 2.7 & 121 & 0.64 & $p<0.01$ & -17.9 & 5.23 & 0.80 & $p<0.01$ & -7.3 & 0.16 & 0.91 & $p<0.01$ \\
\hline $\mathrm{EC}$ & 0.9 & 86.8 & 0.63 & $p<0.01$ & -16.28 & 3.89 & 0.82 & $p<0.01$ & -6.1 & 0.11 & 0.81 & $p<0.01$ \\
\hline
\end{tabular}
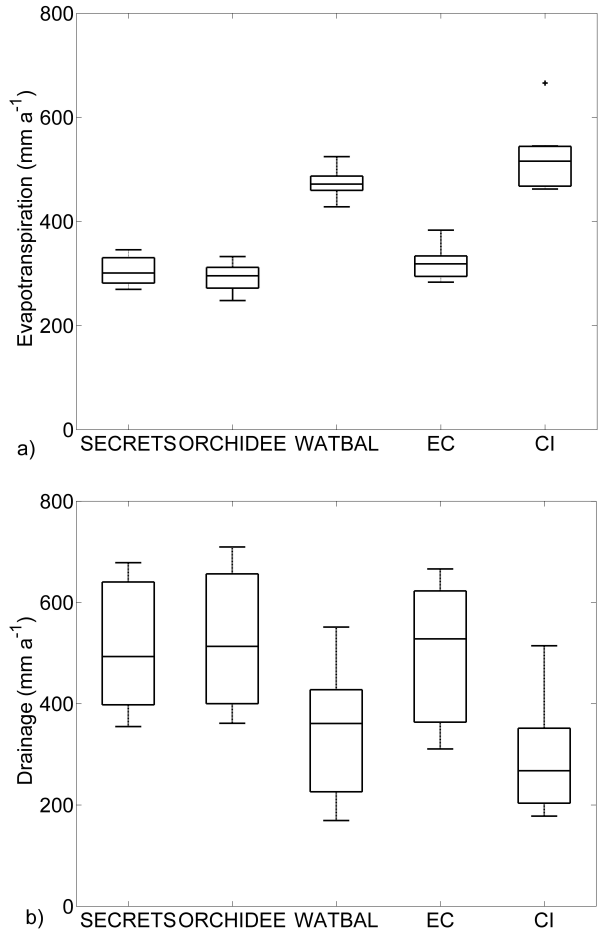

Fig. 5. Box and whisker plots of annual estimates of evapotranspiration (a) and drainage (b) for the five different approaches used in this study. Data represent the period 1997 through 2008 without 1998, 1999 and 2003. Box lines depict the lower (25\%) quartile, median, and upper (75\%) quartile values for each variable. Whiskers, on either end of the box, designate the 95 percentile for each variable. Outliers are represented by the "plus" symbol beyond the ends of the whiskers.

\subsubsection{Seasonal patterns}

We used the seven-year mean monthly estimates of ET and drainage to calculate seasonal patterns in these fluxes for all methods except the CI approach. Seasonal patterns were not possible for the CI estimates because of the ir-
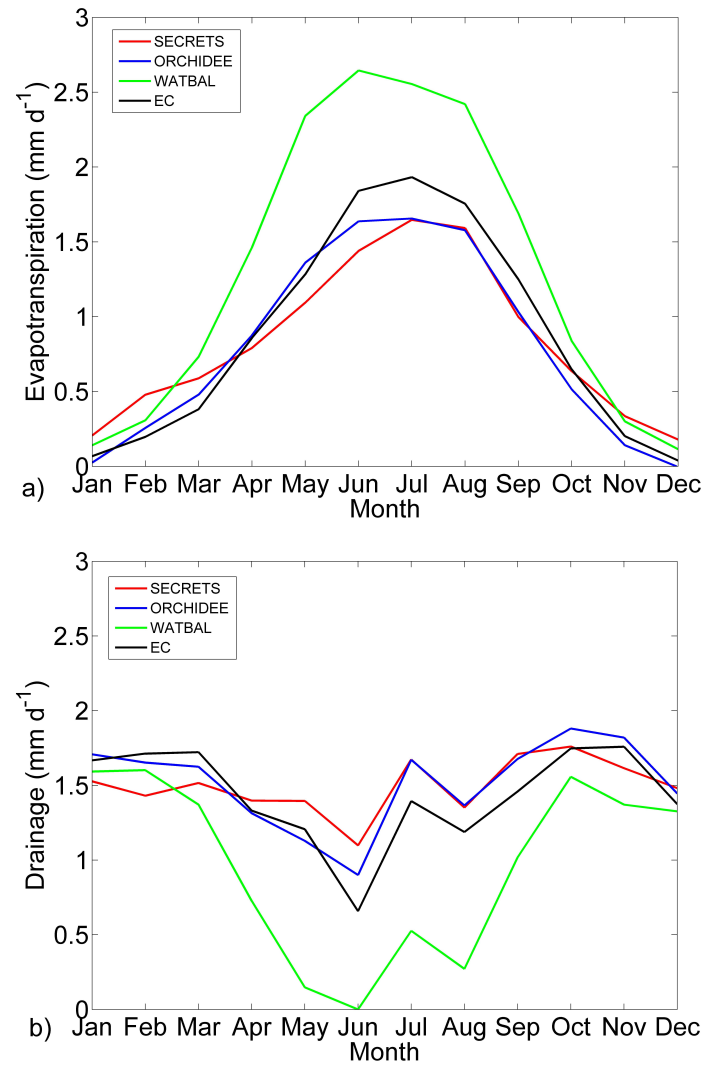

Fig. 6. The seven year mean seasonal patterns of evapotranspiration (ET) (a) and drainage (b) expressed as mm month-1 for ORCHIDEE (blue), SECRETS (red),WATBAL (green) and EC (black). 1998, 1999 and 2003 were excluded because there were no EC data.

regular sampling methodology. Results (Fig. 6a) show that ET reached a maximum in mid-summer. WATBAL followed the same seasonal trends as the other approaches but estimated ca. $46 \%$ more ET $\left(2.4 \mathrm{~mm} \mathrm{~d}^{-1}\right.$ compared to ca. $1.8 \mathrm{~mm} \mathrm{~d}^{-1}$ ) than the process models. The process model estimates of monthly ET were comparable to those measured by the EC approach (Fig. 6a). A monthly mean maximum of 
Table 3. Coefficients for the linear regression analyses between precipitation $\left(\mathrm{mm} \mathrm{month}^{-1}\right)$ and drainage $\left(\mathrm{mm} \mathrm{month}^{-1}\right)$ for the four approaches (SECRETS, ORCHIDEE, WATBAL, eddy covariance [EC]). Included in the table are estimates of the coefficient of determination $\left(r^{2}\right)$ and the $p$-values for each regression analysis.

\begin{tabular}{lrrrr}
\hline & $b$ & $a$ & $r^{2}$ & $p$-value \\
\hline SECRETS & 27.97 & 0.26 & 0.17 & $p<0.01$ \\
ORCHIDEE & 23.13 & 0.34 & 0.22 & $p<0.01$ \\
WATBAL & 26.67 & 0.20 & 0.10 & $p<0.01$ \\
EC & 25.30 & 0.29 & 0.17 & $p<0.01$ \\
\hline
\end{tabular}

$1.5 \mathrm{~mm} \mathrm{~d}^{-1}$ was observed. Because precipitation was evenly distributed throughout the year (data not shown), the seasonal trends of drainage followed an inverse pattern than that of ET (Fig. 6b). Drainage reached a monthly mean maximum in October, varying from $1.5 \mathrm{~mm} \mathrm{~d}^{-1}$ for WATBAL, $1.7 \mathrm{~mm} \mathrm{~d}^{-1}$ for SECRETS, $1.7 \mathrm{~mm} \mathrm{~d}^{-1}$ for the EC fluxes, and $1.8 \mathrm{~mm} \mathrm{~d}^{-1}$ for ORCHIDEE. This maximum in the 7 year mean seasonal pattern was caused by a large drainage flux in October 2000. The monthly mean minimum was achieved in June due to the high ET for the month. The relative difference between the approaches was highest in summer where the difference in ET estimates was also the highest WATBAL reached a monthly mean minimum drainage of $0 \mathrm{~mm} \mathrm{~d}^{-1}$ while the process models did not drop below $1 \mathrm{~mm} \mathrm{~d}^{-1}$.

\subsection{Intra-annual variability}

Total monthly global radiation ( $R g$ ) (Fig. 7a), mean monthly air temperature $\left(T_{\text {air }}\right)$ (Fig. $7 \mathrm{~b}$ ), and mean monthly vapour pressure deficit (VPD) (Fig. 7c) were used to examine the functional relationships between ET and the meteorological variables for each of the five approaches. Linear regression analyses demonstrated that all relationships were statistically significant. The best fits as evaluated using the coefficient of determination $\left(r^{2}\right)$ were found for $R g$ and $T_{\text {air }}$ (Table 1). Overall the lowest $r^{2}$ were found for VPD.

Intra-annual variability in drainage for all approaches, although relations were found significant, was much weaker correlated with total monthly precipitation (Fig. 7d, Table 3) than ET with $R g, T_{\text {air }}$ and even VPD.

\subsection{Interannual variability}

In contrast to intra-annual variability, very few correlations between ET and meteorological variables were significant on annual basis. The CI method was the only approach that even exhibited a negative slope for the regression between ET and all three variables: $R g, T_{\text {air }}$ and VPD. Overall the lowest $r^{2}$ were found for the estimates from WATBAL, except for $R g$ where EC has the lowest $r^{2}$ (Table 4). Also in contrast, inter-
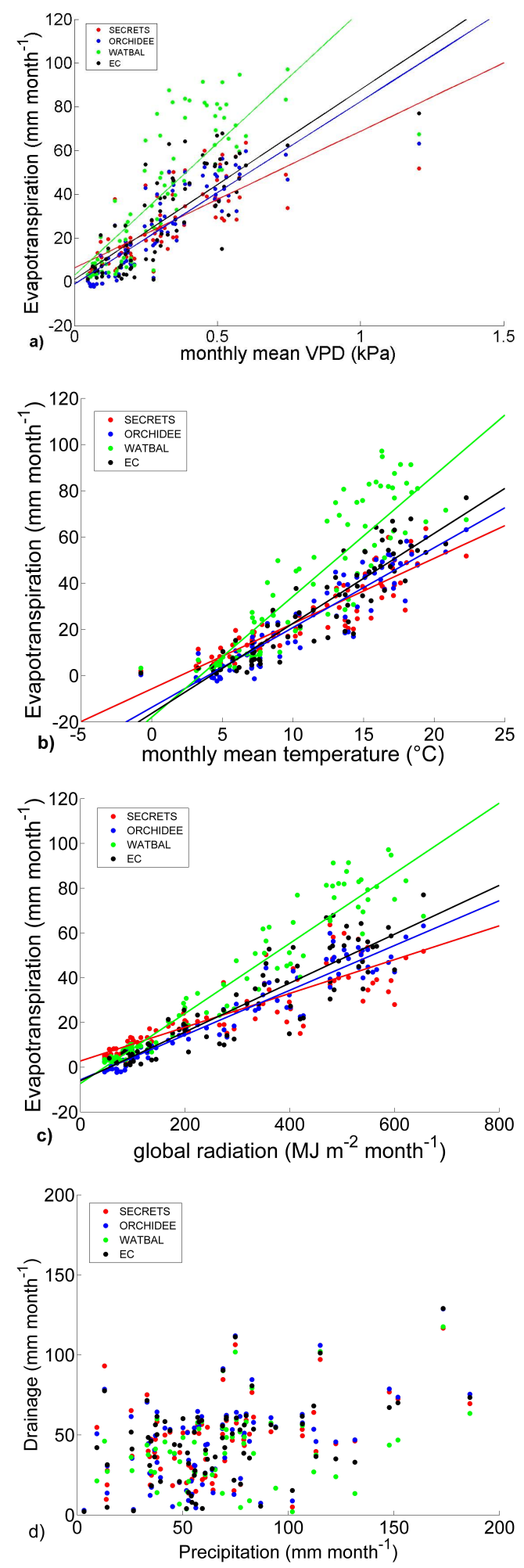

Fig. 7. Linear regression lines for three main drivers of ET on monthly scale for the four different approaches (SECRETS, ORCHIDEE, WATBAL, eddy covariance [EC]) examined in this study. Total global radiation (a), mean annual temperature (b) and mean VPD (c). The lower right panel shows (d) the relation between monthly drainage (ordinate) and precipitation (abscissa). 
annual variability in drainage, for all approaches, was highly correlated with yearly precipitation (Fig. 8d, Table 4).

\section{Discussion}

With the exception of the CI method and WATBAL, our estimates of ET are close to previously reported values. Verstraeten et al. (2005) estimated a yearly ET of $314 \mathrm{~mm}$ for our study site using the empirical model WAVE (Vanclooster et al., 2000). The proportion of transpiration to ET ( 0.55 to 0.65 ) as estimated by OCHIDEE and SECRETS is also comparable to literature values. McLaren et al. (2008) reported that for a temperate Scots pine forest, $47 \%$ of ET could be attributed to transpiration, Oren et al. (1998) reported that transpiration accounted for $69 \%$ of ET in a temperate Loblolly pine (Pinus taeda L.) plantation in North Carolina, USA. Unsworth et al. (2004) reported transpiration to be $65 \%$ of ET in a temperate Douglas fir- Western hemlock (Pseudotsuga menziesii-Tsuga heterophylla) old growth forest, and Grelle et al. (1997) reported 60\% in a boreal mixed conifer (Picea abies-Pinus sylvestris L.) forest. Finally, Kurpius et al. (2003) found that 53\% of ET came from transpiration in a Ponderosa pine (Pinus ponderosa Laws) plantation in California, USA. The rather low ratio at our stand is most likely caused by the low LAI.

The non-linear shape of the relationship between simulated transpiration and that measured from sap flow may, to some extent, be due to storage effects in the stem (Fig. 4). This would indicate that transpiration was under-estimated by sap flow measurements on days with high atmospheric demand, and over-estimated on days with low atmospheric demand. On days with high atmospheric demand, some of the transpired water could come from storage in the stem as observed by Verbeeck et al. (2007). Furthermore the non-linear shape of the curve could be probably also be explained by parameters of the function that is used by the process models to describe the VPD response of stomatal conductance and thus transpiration. Finally, the sap flow measurements exhibited an upper limit, which may suggest limiting hydraulic conductivity in either the stems of the roots, but this physiological limitation is not embedded in the process based models.

Comparing the five different approaches we find relatively good agreement between the two process models (SECRETS and ORCHIDEE) and the EC method. While the empirical models differed more, discrepancies in the relationship between ET simulated by the models and the EC fluxes could be due to several reasons (Fig. 6). Firstly, the absence of understorey ET in the model simulations could cause an underestimation of ET. Due to a change in forest management this understorey, which was removed in the past, has emerged since the beginning of period of this study. It is not possible to reconstruct the succession of this vegetation layer and thus the contribution of the understorey at a given time. Hence,
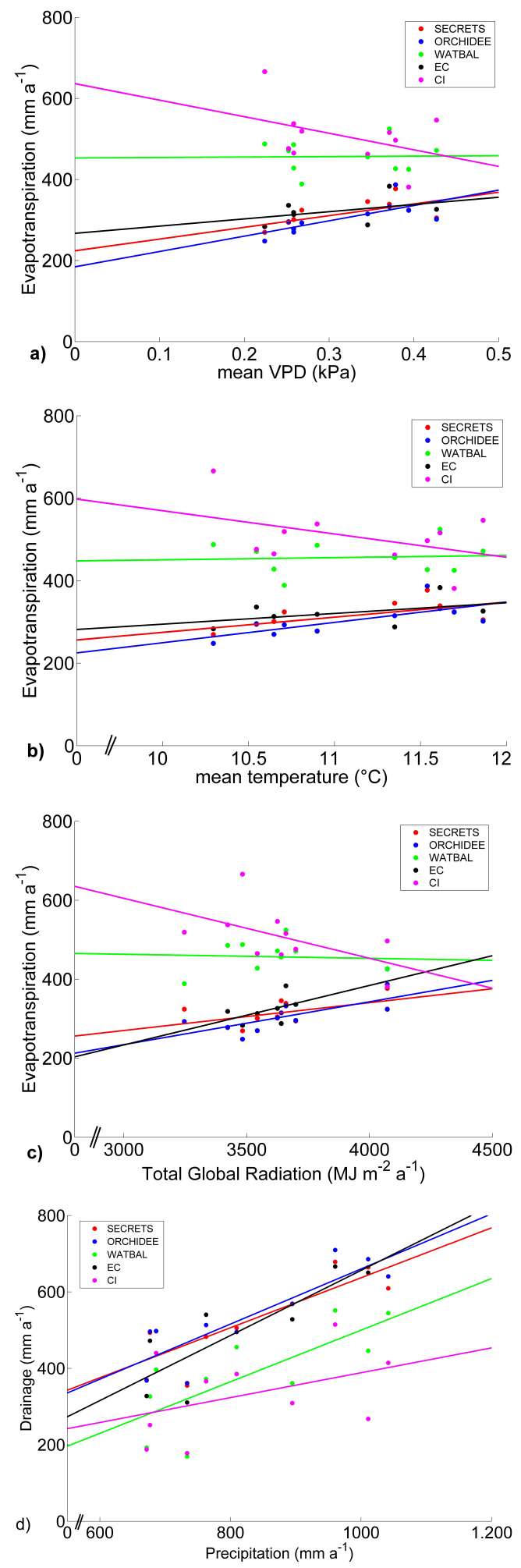

Fig. 8. Linear regression lines for three main drivers of ET on annual scale for the five different approaches (SECRETS, ORCHIDEE, WATBAL, eddy covariance [EC], eddy covariance [EC], Conservative Ion $(\mathrm{CI})$ ) examined in this study. Total global radiation (a), mean annual temperature (b) and mean VPD (c). The lower right panel shows (d) the relation between annual drainage (ordinate) and precipitation (abscissa). 
Table 4. Coefficients for the linear regression analyses between ET (based on annual totals) estimated by the five different approaches (SECRETS, ORCHIDEE, WATBAL, eddy covariance [EC], eddy covariance [EC], Conservative Ion (CI)) and the meteorological variables (i.e., mean yearly VPD; $\mathrm{kPa}$, mean yearly air temperature $\left[T_{\text {air }}\right.$; Celsius] and yearly total global radiation $\left[R g ; \mathrm{MJ} \mathrm{m}^{-2} a^{-1}\right]$ ) for each of the five methods. In all cases the model used was: $y(x)=a^{*} x+b$. Included in the table are estimates of the coefficient of determination $\left(r^{2}\right)$ and the $p$-values for each regression analysis.

\begin{tabular}{|c|c|c|c|c|c|c|c|c|c|c|c|c|}
\hline & \multicolumn{4}{|c|}{ VPD } & \multicolumn{4}{|c|}{$T_{\text {air }}$} & \multicolumn{4}{|c|}{$R g$} \\
\hline & $b$ & $a$ & $r^{2}$ & $p$-value & $b$ & $a$ & $r^{2}$ & $p$-value & $b$ & $a$ & $r^{2}$ & $p$-value \\
\hline SECRETS & 224.2 & 288.6 & 0.41 & 0.05 & -93.7 & 36.8 & 0.39 & 0.05 & 59.0 & 0.07 & 0.31 & 0.09 \\
\hline ORCHIDEE & 184.4 & 378.6 & 0.51 & 0.02 & -243.4 & 49.3 & 0.51 & 0.02 & -90.9 & 0.11 & 0.54 & 0.02 \\
\hline WATBAL & 453.2 & 10.8 & 0.00 & 0.96 & 397.5 & 5.3 & 0.01 & 0.84 & 494.2 & -0.01 & 0.00 & 0.85 \\
\hline $\mathrm{EC}$ & 267.5 & 177.2 & 0.17 & 0.37 & 25.5 & 35.9 & 0.21 & 0.30 & -218.3 & 0.15 & 0.21 & 0.30 \\
\hline CI & 636.4 & -408.3 & 0.16 & 0.25 & 1133.6 & -56.3 & 0.18 & 0.22 & 1060.2 & -0.15 & 0.29 & 0.11 \\
\hline
\end{tabular}

we are not able to give an estimate for the contribution of understorey ET to total stand ET. Omitting the understorey in the model simulation could lead to a significant underestimation of ET. Granier et al. (1989) cited a contribution of $10 \%$ for bilberry understory (Vaccinium myrtillus L.) in a Scots pine forest and Jarosz et al. (2008) reported a contribution of $38 \%$ for purple moor-grass (Molinia coerulea L. Moench) under a maritime Pine forest (Pinus pinaster Ait). However, there could be a trade-off with the simulated soil evaporation. Especially because the contribution of the soil evaporation is high because of the rather low LAI (Wullschleger et al., 1998). A second reason for this deviation could be due to phenology, because a fixed LAI pattern that was measured in 2007 was used for SECRETS for the 10 year period and ORCHIDEE has a sub module that simulates the LAI pattern with a maximum of 1.8. This value was the maximum peakLAI that was measured of the 10 years period. Since the timing of budburst and senescence differs from year to year, using a fixed LAI pattern or attempt to model it could cause deviation between the model estimates of ET and the EC approach. A third possible explanation could be the fact that the EC measurements comprise patches with other tree species, grasses and heathland. The influence of those patches could alter the correlation between the measured fluxes and the model results which are species-specific.

The empirical WATBAL model produces relatively high estimates of ET with an average overestimate of $47 \%$ when compared to the EC fluxes (Fig. 5). The seasonal course of ET shows that the overestimate occurred mostly in summer, while in winter the ET is slightly lower than the EC (Fig. 6). The CI method is considered less useful for these studies as our results show that the ET is overestimated by $58 \%$ when compared to the EC method (Fig. 5a). Additionally, when looking at the correlation between ET and the meteorological variables, the estimates for the CI method show a negative relation with temperature, VPD and $R g$. These odd findings can be explained by the presence of a different autocorrela- tion structure in the chloride time series from soil solution chemistry compared to throughfall chemistry. Additionally, the start and end of the sampling dates varies too much to allow a robust intercomparison on monthly basis.

Highly significant relations were found between ecosystem ET and meterological variables (VPD, $T_{\text {air }}$ and $R g$ ) for all approaches on monthly basis. Several studies reported similar findings where evapotranspiration on seasonal basis was strongly related to VPD (Dolman et al., 2004; Ohta et al., 2001). In contrast to the monthly time scale, few significant relations were found between annual ET and the meteorological variables. Similar conclusions were reported by Ohta et al. (2008) in a seven year water balance study on a larch forest in Siberia. They suggested that interpretation of the major factors controlling evapotranspiration may vary according to the temporal scale used in the analysis. The significant relations between meteorological variables and ET at the monthly timescale could be confounded by factors that change on an annual basis such as LAI, length of growing season and varying understorey. Furthermore, the relations on annual basis could also be diluted by weaker correlations occurring during the long dormant season. In contract, all approaches, except CI, show a significant relation between yearly precipitation and drainage. These strong relations could be explained by the fact that the variation in ET is limited compared to that of precipitation. Consequently, all the excess water is leached out of the ecosystem.

Since our study site is located in a region with ample supply of water, the ET is clearly related to the atmospheric demand (e.g. VPD) and not to water supply (Teuling et al., 2009). Overall, despite the method, the interannual variability in ET over an extensive period of seven year is rather limited. To the authors knowledge only three recent studies have reported long term annual sums of ET measured with eddy covariance. Granier et al. (2008) measured 10 years of ET over a beech forest in Hesse (France), Grünwald and Bernhofer (2007) reported nine years of ET measured over 
Table 5. Coefficients for the linear regression analyses between precipitation $\left(\mathrm{mm} a^{-1}\right)$ and drainage $\left(\mathrm{mm} a^{-1}\right)$ for the five approaches (SECRETS, ORCHIDEE, WATBAL, eddy covariance [EC] and conservative ion $[\mathrm{CI}])$. Included in the table are estimates of the coefficient of determination $\left(r^{2}\right)$ and the $p$-values for each regression analysis.

\begin{tabular}{lrrrr}
\hline & $b$ & $a$ & $r^{2}$ & $p$-value \\
\hline SECRETS & -16.6 & 0.65 & 0.71 & 0.002 \\
ORCHIDEE & -60.9 & 0.72 & 0.74 & 0.002 \\
WATBAL & -174.8 & 0.67 & 0.55 & 0.014 \\
EC & -194.3 & 0.85 & 0.70 & 0.012 \\
CI & 63.4 & 0.33 & 0.17 & 0.232 \\
\hline
\end{tabular}

a spruce forest (Picea abies L.) in Tharandt (Germany) and Ohta et al. (2008) measured ET for seven years over a larch forest (Larix cajanderi Mayr.) in Siberia. All studies find a low interannual variability in ET with mean annual sum and standard deviation of $334 \pm 62 \mathrm{~mm}$ and $475 \pm 45 \mathrm{~mm}$ and $196 \pm 19 \mathrm{~mm}$, respectively.

Uncertainties and future improvements for different approaches:

Eddy covariance:

Uncertainty of eddy covariance fluxes can be divided into two categories: random error and systematic error or bias (Richardson et al., 2006). The first category was calculated and amounted on average to $22 \%$ of the annual total (Table 6). Within our approach the standard deviation within a cluster is a measure for variation caused by other drivers than those included in the Self-Organizing Maps (i.e. leaf area index) and the random error of the measurement. In the absence of systematic errors, our error estimates most likely overestimate the uncertainty of the latend heat observations. Systematic errors, however, are more difficult to estimate. In the past years a lot of research has focused on the problem of the energy balance closure for eddy covariance measurements (Foken, 2008; Oncley et al., 2007; Wilson et al., 2002). Recently Foken (2008) published a review which suggested that the lack of energy balance closure is mainly a problem of scale. The energy balance can only be closed at the landscape scale: firstly, due to differences in footprints between the EC measurements and the other energy balance components and secondly because the eddy covariance is missing contributions from larger eddies. Foken (2008) proposed as a first guess and temporary method to correct the latent fluxes according to the Bowen ratio. However, it is clear that this is not an equivocal method to correct for a possible underestimation of latent heat fluxes measured by eddy covariance and that future research on the energy balance closure is needed to come to a final solution.
Table 6. Random error estimates $(\delta)$ for evapotranspiration measured by eddy covariance (EC), all expressed as $\mathrm{mm} a^{-1}$.

\begin{tabular}{ccc}
\hline Year & EC & $\delta$ \\
\hline 1997 & 336 & 59 \\
2000 & 319 & 93 \\
2001 & 313 & 56 \\
2002 & 283 & 57 \\
2004 & 288 & 74 \\
2005 & 383 & 84 \\
2006 & 326 & 77 \\
\hline
\end{tabular}

Process based models (ORCHIDEE and SECRETS): Uncertainty in biogeochemical process model simulations can arise from multiple sources, ranging from a disparate spectrum of possibilities. This includes potential bias and sampling error in the parameter estimates that drive the empirical and mechanistic processes (e.g., photosynthesis and respiration, inconsistent or erroneous conceptual structure of the linked processes being modeled, and data (Medlyn et al., 2005). To this list we would include errors or misrepresentation in the process algorithms (the code itself) and scaledependencies of the processes being investigated (Jarvis and McNaughton, 1986). Therefore, uncertainty of model simulations made by process based models could be reduced by limiting the uncertainty of the model parameters in addition to evaluation of outputs against long term datasets.

Empirical model (WATBAL):

The uncertainty of the empirical model WATBAL can be attributed to two major causes: firstly, WATBAL uses a Kc factor to convert potential evapotranspiration from well-watered grassland to the potential evapotransiration of a forest. This factor accounts for the coupling of the ecosystem to the atmosphere. Normally forests have a better coupling to the atmosphere than grasslands and thus a $\mathrm{Kc}$ factor higher than 1. However, very few values for the $\mathrm{Kc}$ factor have been published in literature. We decided to use the values published by Meiresonne et al. (2003) as the best approximation however concerning the fact that the stand has a rather low LAI, this Kc factor might be too high. An introduced uncertainty of $10 \%$ on the Kc values resulted in a $6 \%$ uncertainty of the simulated ET (data not shown). Secondly, WATBAL uses a Jensen-Haise model to simulate potential ET or more specifically alfalfa reference crop ET values. This model is based on available radiation and is not as sophisticated as the process based models, which take into account a few other factors such as wind speed, VPD, temperature, $\mathrm{CO}_{2}$ concentration, LAI, etc. WATBAL is thus a useful model to estimate ET over a forested ecosystem when only limited set of data is available for a site. However, one must be aware of the high sensitivity of the model to the Kc factor, which could lead to a significant over-or underestimations of ET. 
Conservative Ions:

Chloride proved to be a nearly inert tracer for long-term computations of downward water fluxes. Unlike sodium (weathering) and sulphate (sorption) it is considered as a conservative ion, although some exchange may occur with the organic molecules (Oberg and Sanden, 2005). The chloride budgets are therefore often used as possible check of results from hydrological models where no water flux measurements are available to partition the precipitation inputs into ET and drainage (De Vries et al., 2001, 2003). Long-term chloride budgets may be expected to be close to zero (De Vries et al., 2001, 2003) and allow therefore for assessing a possible bias in the output from hydrological models. In this case the $\mathrm{Cl}^{-}$ budgets have been calculated for one decade and give therefore some indication whether the order of the magnitude is realistic. For short term calculates of water fluxes from the chloride budget is probably less appropriate because there is a time lag between the $\mathrm{Cl}^{-}$coming in and going out of the soil system. One solution would be to correct for storage of $\mathrm{Cl}^{-}$in the rooting zone in addition to more frequent sampling intensity.

\section{Conclusions}

Although there are several methods to estimate forest water balance, our results suggest that the approach used, and the component examined, must both be considered when choosing a method for study. In this study we compared five commonly used approaches to estimate site water balance. Eddy covariance (EC) estimates of ET are often considered a standard for which to compare alternate approaches. Our results suggest that process model simulations from SECRETS and ORCHIDEE corresponded well to the EC estimates, both on an annual basis and for intra-annual comparisons. Yearly and seasonal patterns were maintained for both models although the models both slightly underestimated annual ET. This underestimation was within the estimated uncertainty ranges of the EC measurements. The Conservative Ion method (CI) and WATBAL both overestimated ET compared to the EC estimates even if the EC fluxes are corrected for energy balance closure.

On monthly scale, good relations could be found between ET and the meteorological variables (i.e., VPD, Air temperature and global radiation). In contrast few significant relations were found on annual time scale. Additionally, small interannual variability in total yearly ET was observed. Consequently, drainage fluxes were highly correlated with annual precipitation for all approaches examined, except CI.
Acknowledgements. The authors would like to thank the ORCHIDEE team at LSCE, Gif-sur-Yvette, France. We are grateful to Fred Kockelberg (UA), Nadine Calluy (UA) and Marc Schuermans (ANB) for technical support. This research was supported by the Centre of Excellence ECO (UA-Methusalem) and the Research Foundation-Flanders (FWO-Vlaanderen).

Edited by: U. Seibt

\section{References}

Aubinet, M., Grelle, A., Ibrom, A., Rannik, U., Moncrieff, J., Foken, T., Kowalski, A. S., Martin, P. H., Berbigier, P., Bernhofer, C., Clement, R., Elbers, J., Granier, A., Grunwald, T., Morgenstern, K., Pilegaard, K., Rebmann, C., Snijders, W., Valentini, R., and Vesala, T.: Estimates of the annual net carbon and water exchange of forests: The EUROFLUX methodology, in: Advances in Ecological Research, Vol 30, Advances in Ecological Research, Academic Press Inc, San Diego, 113-175, 2000.

Baldocchi, D. and Meyers, T.: On using eco-physiological, micrometeorological and biogeochemical theory to evaluate carbon dioxide, water vapor and trace gas fluxes over vegetation: a perspective, Agr. Forest Meteorol., 90, 1-25, 1998.

Barr, A. G., King, K. M., Gillespie, T. J., Denhartog, G., and Neumann, H. H.: A Comparison of Bowen-Ratio and EddyCorrelation Sensible and Latent-Heat Flux Measurements above Deciduous Forest, Bound.-Layer Meteor., 71, 21-41, 1994.

Betts, R. A., Boucher, O., Collins, M., Cox, P. M., Falloon, P. D., Gedney, N., Hemming, D. L., Huntingford, C., Jones, C. D., Sexton, D. M. H., and Webb, M. J.: Projected increase in continental runoff due to plant responses to increasing carbon dioxide, Nature, 448, 1037-1041, 2007.

Blanken, P. D., Black, T. A., Yang, P. C., Neumann, H. H., Nesic, Z., Staebler, R., den Hartog, G., Novak, M. D., and Lee, X.: Energy balance and canopy conductance of a boreal aspen forest: Partitioning overstory and understory components, J. Geophys. Res.-Atmos., 102, 28915-28927, 1997.

Bonan, G. B.: Forests and climate change: Forcings, feedbacks, and the climate benefits of forests, Science, 320, 1444-1449, 2008.

Botta, A., Viovy, N., Ciais, P., Friedlingstein, P., and Monfray, P.: A global prognostic scheme of leaf onset using satellite data, Glob. Change Biol., 6, 709-725, 2000.

Carrara, A., Kowalski, A. S., Neirynck, J., Janssens, I. A., Yuste, J. C., and Ceulemans, R.: Net ecosystem CO2 exchange of mixed forest in Belgium over 5 years, Agricultural and Forest Meteorology, 119, 209-227, 2003.

Cermák, J., Kuèera, J., and Nadezhdina, N.: Sap flow measurements with some thermodynamic methods, flow integration within trees and scaling up from sample trees to entire forest stands, Trees, 18, 529-546, 2004.

Chapin, F. S., Randerson, J. T., McGuire, A. D., Foley, J. A., and Field, C. B.: Changing feedbacks in the climate-biosphere system, Front. Ecol. Environ., 6, 313-320, doi:10.1890/080005, 2008.

De Vries, M., Reinds, G. J., van der Salm, C., Draaijers, G. P., Bleeker, A., Erisman, J. W., Auée, J., Gundersen, P., Kristensen, H. L., van Dobben, H., de Zwart, D., Derome, J., Voogd, J. C. 
H., and Vel, E. M.: Intensive Monitoring of Forest Ecosystems in Europe, Brussels, Geneva, 177 pp.;, 2001.

De Vries, W., Reinds, G. J., Posch, M., Sanz, M. J., Krause, G. H. M., Calatayud, V., Renaud, J. P., Dupouey, J. L., Sterba, H., Vel, E. M., Dobbertin, M., Gundersen, P., and Voogd., J. C. H.: Intensive Monitoring of Forest Ecosystems in Europe, 2003, Brussels, Geneva, 163 pp., 2003.

De Vries, W., W. Wamelink, G.J. Reinds, H.J.J Wieggers, J.P. MolDijkstra, J. Kros, G.J. Nabuurs, A. Pussinen, S. Solberg, M. Dobbertin, D. Laubhann, H. STerba, and Oijen, M.: Assessment of the relative importance of nitrogen deposition climate change and forest management on the sequestration of carbon by forests in Europe, Alterra, Wageningen, 302 pages, 361 figs., 394 tables, 469 refs, 2007.

dePury, D. G. G. and Farquhar, G. D.: Simple scaling of photosynthesis from leaves to canopies without the errors of big-leaf models, Plant Cell Environ., 20, 537-557, 1997.

Dolman, A. J., Maximov, T. C., Moors, E. J., Maximov, A. P., Elbers, J. A., Kononov, A. V., Waterloo, M. J., and van der Molen, M. K.: Net ecosystem exchange of carbon dioxide and water of far eastern Siberian Larch (Larix cajanderii) on permafrost, Biogeosciences, 1, 133-146, 2004, http://www.biogeosciences.net/1/133/2004/

Ducoudre, N. I., Laval, K., and Perrier, A.: Sechiba, a New Set of Parameterizations of the Hydrologic Exchanges at the Land Atmosphere Interface within the Lmd Atmospheric GeneralCirculation Model, J. Climate, 6, 248-273, 1993.

Eriksson, E. and Khunakasem, V.: Chloride concentration in groundwater, recharge rate and rate of deposition of chloride., J. Hydrol., 7, 178-197, 1969.

Foken, T.: The energy balance closure problem: An overview, Ecol. Appl., 18, 1351-1367, 2008.

Gond, V., de Pury, D. G. G., Veroustraete, F., and Ceulemans, R.: Seasonal variations in leaf area index, leaf chlorophyll, and water content; scaling-up to estimate fAPAR and carbon balance in a multilayer, multispecies temperate forest, Tree Physiol., 19, 673$679,1999$.

Granier, A., Loustau, D., Saugier, B., and Berbigier, P.: Bilan hydrique de deux peuplements de pin maritime dans les Landes: évaluation des flux des strates ligneuse et herbacée et de leur variabilité., in: ATP PIREN, Influence à l'échelle régionale des couvertures pédologiques et végétales sur les bilans hydriques et minéraux du sol., 287-315, 1989.

Granier, A., Breda, N., Longdoz, B., Gross, P., and Ngao, J.: Ten years of fluxes and stand growth in a young beech forest at Hesse, North-eastern France, Ann. For. Sci., 65, 704, doi:10.1051/forest:2008052, 2008.

Grelle, A., Lundberg, A., Lindroth, A., Morén, A. S., and Cienciala, E.: Evaporation components of a boreal forest: variations during the growing season, J. Hydrol., 197, 70-87, 1997.

Grünwald, T. and Bernhofer, C.: A decade of carbon, water and energy flux measurements of an old spruce forest at the Anchor Station Tharandt, Tellus B, 59, 387-396, 2007.

Hanson, P. J., Amthor, J. S., Wullschleger, S. D., Wilson, K. B., Grant, R. F., Hartley, A., Hui, D., Hunt, E. R., Johnson, D. W., Kimball, J. S., King, A. W., Luo, Y., McNulty, S. G., Sun, G., Thornton, P. E., Wang, S., Williams, M., Baldocchi, D. D., and Cushman, R. M.: Oak forest carbon and water simulations: Model intercomparisons and evaluations against indepen- dent data, Ecol. Monogr., 74, 443-489, 2004

Huntington, T. G.: Evidence for intensification of the global water cycle: Review and synthesis, J. Hydrol., 319, 83-95, 2006.

Jackson, R. B., Randerson, J. T., Canadell, J. G., Anderson, R. G., Avissar, R., Baldocchi, D. D., Bonan, G. B., Caldeira, K., Diffenbaugh, N. S., Field, C. B., Hungate, B. A., Jobbagy, E. G., Kueppers, L. M., Nosetto, M. D., and Pataki, D. E.: Protecting climate with forests, Environ. Res. Lett., 3, 044006, doi:044010.041088/041748049326/044003/044004/044006, 2008.

Jarosz, N., Brunet, Y., Lamaud, E., Irvine, M., Bonnefond, J.-M., and Loustau, D.: Carbon dioxide and energy flux partitioning between the understorey and the overstorey of a maritime pine forest during a year with reduced soil water availability, Agr. Forest Meteorol., 148, 1508-1523, 2008.

Jarvis, P. G. and McNaughton, K. G.: Stomatal Control of Transpiration - Scaling up from Leaf to Region, Adv. Ecol. Res., 15, 1-49, 1986.

Jensen, M. E. and Haise, H. R.: Estimating evapotranspiration from solar radiation, J. Irrig. Drain. E-Asce, 89, 15-41, 1963.

Kelliher, F. M., Black, T. A., and Price, D. T.: Estimating the Effects of Understory Removal from a Douglas-Fir Forest Using a 2-Layer Canopy Evapotranspiration Model, Water Resour. Res., 22, 1891-1899, 1986

Kohonen, T.: Self-Organizing Maps, 3. Edn., Springer series in information sciences, Springer-Verlag, Berlin, 501 pp., 2001.

Konopka, B., Yuste, J. C., Janssens, I. A., and Ceulemans, R.: Comparison of fine root dynamics in scots pine and pedunculate oak in sandy soil, Plant Soil, 276, 33-45, 2005.

Kowalski, A. S., Overloop, S., Ceulemans, R.: Eddy fluxes above a Belgian, Campine forest and their relationship with predicting variables, in: Forest Ecosystem Modelling, Upscaling and Remote Sensing, edited by: Ceulemans, R., Veroustraete, F., Gond, V., and Van Rensbergen, J., SPB Academic Publishing, The Hague, The Netherlands, 3-17, 2000.

Krinner, G., Viovy, N., de Noblet-Ducoudre, N., Ogee, J., Polcher, J., Friedlingstein, P., Ciais, P., Sitch, S., and Prentice, I. C.: A dynamic global vegetation model for studies of the coupled atmosphere-biosphere system, Glob. Biogeochem. Cycle, 19, GB1025, doi:1010.1029/2003GB002199, 2005.

Kurpius, M. R., Panek, J. A., Nikolov, N. T., McKay, M., and Goldstein, A. H.: Partitioning of water flux in a Sierra Nevada ponderosa pine plantation, Agr. Forest Meteorol., 117, 173-192, 2003.

Leuning, R.: A Critical-Appraisal of a Combined StomatalPhotosynthesis Model for C-3 Plants, Plant Cell Environ., 18, 339-355, 1995.

Luyssaert, S., Janssens, I. A., Sulkava, M., Papale, D., Dolman, A. J., Reichstein, M., Hollmen, J., Martin, J. G., Suni, T., Vesala, T., Loustau, D., Law, B. E., and Moors, E. J.: Photosynthesis drives anomalies in net carbon-exchange of pine forests at different latitudes, Glob. Change Biol., 13, 2110-2127, 2007.

McLaren, J. D., Arain, M. A., Khomik, M., Peichl, M., and Brodeur, J.: Water flux components and soil wateratmospheric controls in a temperate pine forest growing in a well-drained sandy soil, J. Geophys. Res., 113, G04031, doi:04010.01029/02007JG000653, 2008.

McMurtrie, R. E. and Landsberg, J. J.: Using a simulation model to evaluate the effects of water and nutrients on the growth and 
carbon partitioning of Pinus radiata, Forest Ecol. Manag., 52, 243-260, 1992.

Medlyn, B. E., Robinson, A. P., Clement, R., and McMurtrie, R. E.: On the validation of models of forest $\mathrm{CO} 2$ exchange using eddy covariance data: some perils and pitfalls, Tree Physiol, 25, 839-857, doi:10.1093/treephys/25.7.839, 2005.

Meiresonne, L., Sampson, D. A., Kowalski, A. S., Janssens, I. A., Nadezhdina, N., Cermak, J., Van Slycken, J., and Ceulemans, R.: Water flux estimates from a Belgian Scots pine stand: a comparison of different approaches, J. Hydrol., 270, 230-252, 2003.

Nadezhdina, N., Tributsch, H., and Cermak, J.: Infra-red images of heat field around a linear heater and sap flow in stems of lime trees under natural and experimental conditions, Ann. For. Sci., 61, 203-213, 2004.

Nadezhdina, N., Cermak, J., Gasparek, J., Nadezhdin, V., and Prax, A.: Vertical and horizontal water redistribution in Norway spruce (Picea abies) roots in the Moravian Upland, Tree Physiol., 26, 1277-1288, 2006.

Nadezhdina, N. a. J. C.: The technique and instrumentation for estimation the sap flow rate in plants, Patent No. 286438 (PV-158798), 2000.

Oberg, G., and Sanden, P.: Retention of chloride in soil and cycling of organic matter-bound chlorine, Hydrol. Process., 19, 21232136, 2005.

Ohta, T., Hiyama, T., Tanaka, H., Kuwada, T., Maximov, T. C., Ohata, T., and Fukushima, Y.: Seasonal variation in the energy and water exchanges above and below a larch forest in eastern Siberia, Hydrol. Process., 15, 1459-1476, 2001.

Ohta, T., Maximov, T. C., Dolman, A. J., Nakai, T., van der Molen, M. K., Kononov, A. V., Maximov, A. P., Hiyama, T., Iijima, Y., Moors, E. J., Tanaka, H., Toba, T., and Yabuki, H.: Interannual variation of water balance and summer evapotranspiration in an eastern Siberian larch forest over a 7-year period (1998-2006), Agr. Forest Meteorol., 148, 1941-1953, 2008.

Oja, M., Kaski, S., and Kohonen, T.: Bibliography of SelfOrganizing Map (SOM) Papers: 1998-2001 Addendum, Neural Comput., 1, 1-176, 2002.

Oncley, S. P., Foken, T., Vogt, R., Kohsiek, W., DeBruin, H. A. R., Bernhofer, C., Christen, A., van Gorsel, E., Grantz, D., Feigenwinter, C., Lehner, I., Liebethal, C., Liu, H., Mauder, M., Pitacco, A., Ribeiro, L., and Weidinger, T.: The Energy Balance Experiment EBEX-2000, Part I: Overview and energy balance, Bound.-Layer Meteor., 123, 1-28, 2007.

Op de Beeck, M., Gielen, B., Jonckheere, I., Samson, R., Janssens, I. A., and Ceulemans, R.: Needle age-related and seasonal photosynthetic capacity variation is negligible for modelling yearly gas exchange of a sparse temperate Scots pine forest, Biogeosciences, 7, 199-215, 2010,

http://www.biogeosciences.net/7/199/2010/.

Oren, R., Phillips, N., Katul, G., Ewers, B. E., and Pataki, D. E.: Scaling xylem sap flux and soil water balance and calculating variance: a method for partitioning water flux in forests, Ann. Sci. For., 55, 191-216, 1998.

Papale, D., Reichstein, M., Aubinet, M., Canfora, E., Bernhofer, C., Kutsch, W., Longdoz, B., Rambal, S., Valentini, R., Vesala, T., and Yakir, D.: Towards a standardized processing of Net Ecosystem Exchange measured with eddy covariance technique: algorithms and uncertainty estimation, Biogeosciences, 3, 571-583, 2006 , http://www.biogeosciences.net/3/571/2006/.

Reichstein, M., Falge, E., Baldocchi, D., Papale, D., Aubinet, M., Berbigier, P., Bernhofer, C., Buchmann, N., Gilmanov, T., Granier, A., Grunwald, T., Havrankova, K., Ilvesniemi, H., Janous, D., Knohl, A., Laurila, T., Lohila, A., Loustau, D., Matteucci, G., Meyers, T., Miglietta, F., Ourcival, J. M., Pumpanen, J., Rambal, S., Rotenberg, E., Sanz, M., Tenhunen, J., Seufert, G., Vaccari, F., Vesala, T., Yakir, D., and Valentini, R.: On the separation of net ecosystem exchange into assimilation and ecosystem respiration: review and improved algorithm, Glob. Change Biol., 11, 1424-1439, 2005.

Richardson, A. D., Hollinger, D. Y., Burba, G. G., Davis, K. J., Flanagan, L. B., Katul, G. G., Munger, J. W., Ricciuto, D. M., Stoy, P. C., Suyker, A. E., Verma, S. B., and Wofsy, S. C.: A multi-site analysis of random error in tower-based measurements of carbon and energy fluxes, Agr. Forest Meteorol., 136, 1-18, 2006.

Rutter, A.: The hydrological cycle vegetation, edited by: Montheith, J. L., Vegetation and atmosphere, Vol I. Academic press, London, 111-154, 1975.

Sahin, V. and Hall, M. J.: The effects of afforestation and deforestation on water yields, J. Hydrol., 178, 293-309, 1996.

Sampson, D. A. and Ceulemans, R.: SECRETS: simulated carbon fluxes from a mixed coniferous/deciduous forest, In Forest Ecosystem Modeling, Upscaling and Remote Sensing 95-108, 2000 .

Sampson, D. A., Janssens, I. A., and Ceulemans, R.: Simulated soil $\mathrm{CO} 2$ efflux and net ecosystem exchange in a 70-year-old Belgian Scots pine stand using the process model SECRETS, Ann. For. Sci., 58, 31-46, 2001.

Sampson, D. A., Janssens, I. A., and Ceulemans, R.: Under-story contributions to stand level GPP using the process model SECRETS, Agr. Forest Meteorol., 139, 94-104, 2006.

Saxton, K. E., Rawls, W. J., Romberger, J. S., and Papendick, R. I.: Estimating Generalized Soil-Water Characteristics from Texture, Soil Sci. Soc. Am. J., 50, 1031-1036, 1986.

Shukla, J. and Mintz, Y.: Influence of Land-Surface EvapoTranspiration on the Earths Climate, Science, 215, 1498-1501, 1982.

Starr, M.: A model for estimating monthly water balance components, including soil water fluxes, in: 8th Annual Report 1999, ICP Integrated Monitoring, edited by: Kleemola, S. and Forsius, M., Finnish Environment Institute, Helsinki, Finland, 31$35,1999$.

Teuling, A. J., Hirschi, M., Ohmura, A., Wild, M., Reichstein, M., Ciais, P., Buchmann, N., Ammann, C., Montagnani, L., Richardson, A. D., Wohlfahrt, G., and Seneviratne, S. I.: A regional perspective on trends in continental evaporation, Geophys. Res. Lett., 36, L02404, doi:02410.01029/02008GL036584, 2009.

Thornthwaite, C. W. and Mather, J. R.: Instructions and tables for computing potential evapotranspiration and the water balance, Laboratory of Climatology, Centerton, NJ, 1957.

Twine, T. E., Kustas, W. P., Norman, J. M., Cook, D. R., Houser, P. R., Meyers, T. P., Prueger, J. H., Starks, P. J., and Wesely, M. L.: Correcting eddy-covariance flux underestimates over a grassland, Agr. Forest Meteorol., 103, 279-300, 2000.

Unsworth, M. H., Phillips, N., Link, T., Bond, B. J., Falk, M., Harmon, M. E., Hinckley, T. M., Marks, D., and U, K. T. P.: Components and controls of water flux in an old-growth Douglas-fir- 
western hemlock ecosystem, Ecosystems, 7, 468-481, 2004.

Vanclooster, M., Viaene, P., Diels, J., and Christiaens, K.: WAVE, a mathematical model for simulating water and agrochemicals in the soil and vadose environment. Reference and user's manual, Release 2.0., Institute for Land and Water Management, Katholieke Universiteit Leuven, Leuven, 144 pp., 2000.

Verbeeck, H., Steppe, K., Nadezhdina, N., Op de Beeck, M., Deckmyn, G., Meiresonne, L., Lemeur, R., Cermak, J., Ceulemans, R., and Janssens, I. A.: Stored water use and transpiration in Scots pine: a modeling analysis with ANAFORE, Tree Physiol., 27, 1671-1685, 2007.

Verstraeten, W. W., Muys, B., Feyen, J., Veroustraete, F., Minnaert, M., Meiresonne, L., and De Schrijver, A.: Comparative analysis of the actual evapotranspiration of Flemish forest and cropland, using the soil water balance model WAVE, Hydrol. Earth Syst. Sci., 9, 225-241, 2005, http://www.hydrol-earth-syst-sci.net/9/225/2005/.

Wilson, K., Goldstein, A., Falge, E., Aubinet, M., Baldocchi, D., Berbigier, P., Bernhofer, C., Ceulemans, R., Dolman, H., Field, C., Grelle, A., Ibrom, A., Law, B. E., Kowalski, A., Meyers, T., Moncrieff, J., Monson, R., Oechel, W., Tenhunen, J., Valentini, R., and Verma, S.: Energy balance closure at FLUXNET sites, Agr. Forest Meteorol., 113, 223-243, 2002.
Wilson, K. B., Hanson, P. J., Mulholland, P. J., Baldocchi, D. D., and Wullschleger, S. D.: A comparison of methods for determining forest evapotranspiration and its components: sap-flow, soil water budget, eddy covariance and catchment water balance, Agr. Forest Meteorol., 106, 153-168, 2001.

WRB, I. W. G.: World reference base for soil resources, 2nd ed., World soil resources reports no. 103, FAO, Rome, 2006.

Wullschleger, S. D., Hanson, P. J., and Tschaplinski, T. J.: Wholeplant water flux in understory red maple exposed to altered precipitation regimes, Tree Physiol., 18, 71-79, 1998.

Xiao, C. W., Yuste, J. C., Janssens, I. A., Roskams, P., Nachtergale, L., Carrara, A., Sanchez, B. Y., and Ceulemans, R.: Above- and belowground biomass and net primary production in a 73-yearold Scots pine forest, Tree Physiol., 23, 505-516, 2003.

$\mathrm{Xu}$, C. Y. and Singh, V. P.: A Review on Monthly Water Balance Models for Water Resources Investigations, Water Resour. Manag., 12, 20-50, 1998.

Yuste, J. C., Konopka, B., Janssens, I. A., Coenen, K., Xiao, C. W., and Ceulemans, R.: Contrasting net primary productivity and carbon distribution between neighboring stands of Quercus robur and Pinus sylvestris, Tree Physiol., 25, 701-712, 2005. 